Article

\title{
Criminal Desistance Narratives of Young People in the West of Scotland: Understanding Spirituality and Criminogenic Constraints
}

\author{
Chris Holligan and Robert McLean * \\ School of Education, Interdisciplinary Research Unit on Crime, Policing and Social Justice, \\ University of the West of Scotland, Ayr Campus, Ayr KA8 0SX, UK; Chris.holligan@uws.ac.uk \\ * Correspondence: robert.mclean@uws.ac.uk; Tel.: +44-077-098-5940
}

Received: 21 March 2018; Accepted: 17 May 2018; Published: 28 May 2018

\begin{abstract}
In our qualitative study of urban youth living in the West of Scotland, we argue that religion and spirituality give personal sustenance and hope from which a process of desistance can emerge. Religious worship offers a 'site' for undermining reoffending through the availability and adoption of socially supportive bonds. Desistance can occur through the development of different bonds and the recognition of transcendental authority. The results endorse the protective role of spirituality in desistance in relation to disadvantaged young people whose lives have been impacted by crime.
\end{abstract}

Keywords: desistance; religion; spirituality; crime; structure; offending

\section{Desistance and Religiosity}

Desistance is shaped when the former offender's identity becomes pro-social and self-critical in an enduring manner. The emergence of such identities predicts patterns of criminal desistance over the life course (Rocque et al. 2016). Classic scholarship in sociology and social psychology addresses the development of selfhood typically through stage perspectives (Erikson 1968; Goffman 1959). Adolescent youth is conceptualised in terms of transitional identities where the self becomes especially vulnerable as it progresses from the stage of childhood towards early adulthood. This is likened to a separation from a family-oriented identity to one that is more affiliated and supported by age peers. It is during this period that the separate sense of self-identity combined with independence emerges often after considerable "storm and stress" (Hall 1904).

Rocque et al. (2016), in their predictive longitudinal study of identity and desistance, found staunch support for identity change theories of desistance (Giordano et al. 2002; Maruna 2001). They concluded that a theory of desistance should embrace the role of "subjective" factors such as the former offender's identity. However, they cautioned against optimism, with the caveat that desistance entails a combination of structure and agency. Identity change requires a certain type of contest in order for it to be authentically activated. Identity theories of desistance assume that for social control processes to have an impact on behaviour, social bonds are significant, a factor pervading classic treatments of desistance (Hirschi 1969). In this vein, Rocque et al. (2016) concluded that "our findings are supportive of 'redemption' policies", where a focus on the criminal identity is central. Community re-integration, upon which desistance is a fortiori dependent, demands criminal justice policies that recognise the consistent role of identity change in desistance outcomes. Prison or other related programmes that enable offenders to 'design' new narrative identities are therefore to be welcomed. Their caveat about the additional requirement for supportive environmental structures to establish the pre-conditions that allow a meaningful purchase of "redemption" cannot be underestimated, as our own data demonstrate. 
Reoffending rates after release from prison tend to be high in most Western countries (Beijersbergen et al. 2016). These scholars argue that post-release recidivism is influenced by experiences of custodial treatment; Dutch prisoners who felt they had been approached respectfully were found to be less likely to reoffend within 18 months after release. A deterrence perspective holds that a reduction in reoffending rates occurs as the benefit of compliance exceeds its costs. Legitimacy is projected through procedurally respectful and just treatment: legitimacy as conceived by scholars in this area is understood in secular, rather than transcendental or spiritual terms, which is indicative of a gap in our knowledge about how it is perceived and socially constructed. Social support is a dimension of religious practice, and is "of great importance to most religious people"; those who pray "are healthier and recover from illness better than those who do not" (Breakey 2001, p. 63).

Beliefs in a higher power have been associated with grief through ritual and process which may, as we describe in the context of desistance, manifest as an epiphany rather than a gradual process of self-identity transformation, or an inexplicable feeling of transcendental support replacing the grief of loss and psychic disruption of well-being (Wayland et al. 2016). One trope of the complexity of desistance is captured through the image of "desister as nomad"; here, its "endless and multiplicitous" quiddity is foregrounded (Philipps 2017, p. 92). Hallett and McCoy (2014, p. 868) claim that "pathways to desistance involve highly subjective assessments of agency and structure", thus illustrating not only its complexity, but also the individual heterogeneity of routes to desistance, which more recent statistical research has demonstrated is premised upon the emergence of pro-social identities (Rocque et al. 2016). The question of how to judge the point at which desistance has occurred is an unresolved issue in the literature. Desistance is defined as the underlying process resulting in the termination of anti-social behaviour and criminal activity (Laub and Sampson 2001); it is the sustained absence of an event, impacted by concatenations of psychological and sociological processes (Maruna 2001). Lofland (1969) argued that people's views about themselves as either conformist or deviant impact on the ways in which they behave.

Spirituality and religion are not treated as mutually exclusive by criminologists who are interested in criminal desistance (Hallett and McCoy 2014, p. 856). Young people's perceived spirituality has been understood as a developmental asset that is linked with thriving behaviours, giving inner strength and the inclination to contribute positively to social institutions (Warren et al. 2012). While a large body of knowledge has been accumulated about risk factors for the development of anti-social behaviour, less is known about the later desistance of youths entering adulthood (Aiyer 2014). Studies by Ttofi et al. $(2016 \mathrm{a}, 2016 \mathrm{~b})$ both found the development of certain attributes, such as intelligence, either via the ageing process or an effort to act, as protective factors against offending behaviour. Nevertheless, some important truths have crystallised about risk of offending and desistance: the importance of social and institutional bonds is a theme running throughout foundational work in this field (Sampson and Laub 1993; Laub and Sampson 2001).

"Spiritual but not religious" perspectives inform the practices of today's spiritual teachers (Gottlieb 2012). Scholars argue that religion has potential as a mechanism for desistance because of the overlap between its core concerns in religious communities, religious texts, and offenders' problem areas (Hallett and McCoy 2014, p. 856). Religiosity refers to belief in a Creator and observance, whether public or private, of an organised religion (Hardy et al. 2013; Holder et al. 2016; Kim-Spoon et al. 2014; Michaelson et al. 2014; Salas-Wright et al. 2017; Schiff 2006 and Shepperd et al. 2015). Several studies have found that higher levels of religiosity act as an important protective buffer linked with less risky or unhealthy behaviour and less substance misuse (Hardy et al. 2013; Kim-Spoon et al. 2014; Michaelson et al. 2014; Schiff 2006) and, to some extent, they are a predictor of well-being (Holder et al. 2016; Michaelson et al. 2014). A seminal study by Hardy et al. (2013), for example, found that religiosity had a protective effect against pornography to be present in adolescents with higher levels of religiosity; this "protective effect" finding conforms with the findings not only of Kim-Spoon et al. (2014), but also with those of Michaelson et al. (2014) and Schiff (2006). 
The protective effect of high religiosity against unhealthy behaviour is also in accordance with the findings of Shepperd et al. (2015), who found that greater religiosity corresponded to lower levels of direct and indirect aggression. Greater religiosity was also associated with higher levels of compassion, and both Hardy et al. (2013) and Shepperd et al. (2015) found greater religiosity to be associated with more self-control. In their study of 419 children aged 15-18, Hardy et al. (2013) found that adolescents who were more religiously involved and had more deeply internalised religious motivations had greater self-regulation, more conservative attitudes towards pornography, and stronger social norms against pornography. These adolescents would also view pornography less frequently, whether intentionally or accidentally (Hardy et al. 2013).

Spirituality has been understood as the pursuit of spiritual virtues and one of the elements of traditional religion (Gottlieb 2012). Youths with coherent ideas of being spiritual have scored highest on measures of positive development (James and Fine 2015). Hallett and McCoy (2014) examined the life history narratives of 25 successful ex-offenders who professed Christianity as the source of their desistance. Their behaviour change and identity transformation was achieved through private religious practice and energetic church membership. Each of these experiences altered their subjectivities. Our examination of the altered subjectivity through psychiatric interventions that are informed by religion networks our paper with the ameliorative role of religion in mental health, which is a theme emerging from our earlier discussion of protective factors. The editorial of one leading psychiatric journal stated that "after decades of neglecting spirituality and religion in psychiatric discourse, research programmes are delineating the relationships between spirituality and health and casting light upon the processes by which spirituality may have positive effects" (Breakey 2001, p. 61). The "mutual suspicion" mentioned in this editorial between these areas and psychiatry carry parallels with criminology, and a common scepticism that may relate to the trend towards secularism in the West (Bruce 2002). That over $90 \%$ of prisoners have a mental disorder encourages us to take seriously interconnections between well-being with faith (Birmingham 2003, p. 191; Fazel and Baillargeon 2011).

\section{Methodology}

Qualitative methods afford the generation of inductively developed knowledge and understanding, and are typically utilised to pursue research into populations that are hidden or difficult to reach (Flick 2009; Hallett and McCoy 2014). In-depth interviews enable the researcher to achieve insight into the way individuals understand events and situations. The narratives presented are derived from fieldwork undertaken during 2013-2016 as part of a larger qualitative study addressing gang organisation as a means for gang business. Our qualitative interviews, lasting for about $60 \mathrm{~min}$, were conducted individually and taped with a digital recorder following informed consent by the research participants, all of whom had criminal convictions and most of whom had been incarcerated in young offenders' prisons. Our sample numbered 35 persons who took part in in-depth interviews. They all had lengthy offending histories and had been participants in organised criminal activity (Scottish Government 2015). The interviewees were all male, apart from one, and classed themselves as an indigenous West of Scotland population; not all were white. The participants came from self-defined working-class backgrounds; the majority were domiciled in Scotland's $20 \%$ most socially deprived communities (Scottish Government 2012). While participants have the characteristics of life-course offenders, for ethical purposes, it was essential that they had to be seriously engaged in the desistance process in order to be included in our sample; it was evident that this commitment varied amongst participants.

Street workers attached to church-based outreach projects in the West of Scotland acted as initial gatekeepers to help us access the appropriate research participants. Following difficulties associated with accessing other hard-to-reach populations-given their participation in (re)offending-a snowball sampling technique via gatekeepers was deployed to access wider sample populations (Bhopal and Deuchar 2016). Becker (1963) suggests that this is relevant where the sampling frame is 
limited. Accordingly, street workers and interviewed participants were asked to recommend additional appropriate contacts who would consider participation.

Deploying open-ended interview techniques allowed the interviewees to convey their unrestricted, distinct subjective experience of internal dynamics within familiar environments. Efforts were undertaken to keep interview questions open so that the researcher could be responsive to emerging data, and participants had scope to articulate. Data was recorded via audio devices and then analysed thematically (Creswell 1994). Ethical approval to undertake the study was granted by the researchers' university. Prior to interviews, an information sheet outlining relevant information was distributed to participants. Our general research questions in relation to desistance covered the following issues: What motivated participants to cease offending behaviour? How did the participants initially engage in desistance? Did spirituality play a role in the desistance process? Why did some participants reoffend? These questions arose from our analysis of the literature and reflect our judgement that they required further research attention.

\section{Findings}

\subsection{Spirituality as Redemptive Capital}

Hallett and McCoy (2014) qualitative study of offenders in the US shares clear similarities with our investigation, and offers an appropriate grounding for our spirituality theme. Their sample of 25 offenders had convictions for serious crimes and comprised non-denominational Protestants, Catholics, and Southern Baptists with an average age of 47. Previous studies have demonstrated that successful desistance occurs once exposure to spirituality and religion has enabled a reconceptualisation of identity (Maruna 2001; Hallett and McCoy 2014). These intangible nurturing and supportive resources are especially important where there is limited emotional and informal social support (Maruna 2001), as in the life context of disadvantage that was experienced by our own sample. The mechanisms involved in this type of desistance context relate to the forms that capital offenders have engaged with; religion and spirituality can be utilised as resources to create stories of change and foster an alternative selfhood (Paternoster and Bushway 2009). So, religiosity drives embryonic agency where a pro-social sense of being may emerge (Maruna and Ramsden 2004).

In each of the extracts below, the theme of behavioural control is raised in different forms and arguments; these nuances resonate with the individualistic subjectivity argument about desistance pathways (Hallett and McCoy 2014, p. 869). Maruna et al. (2004) suggest that the encouragement of spiritual practices within rehabilitative and intervention programmes plays a significant role in increasing civility and commitment to desistance. Control through conformity to localised criminal codes of behaviour and a dark morality emerged from our fieldwork, where shifting towards religiosity inspired a switch to a transcendental code of morality. The control effects of religiosity can involve fear of supernatural sanctions and the projection of conventional strictures of behaviour (Hirschi 1969). Participant James described his experience:

I was already quite self-controlled, even though I had always been up to no good. I mean, doing the line of work that I did in the area, you got to be. No one would work wi' a hot-head. At the same time, you sometimes need to make [a] decision you might not actually agree with, like morally ... . But you can justify it if you know what I mean. Say a guy needs his legs broken .... You might think he is sound (likeable) but if he had been out of line then you need to sanction him. Like in the criminal world that's justifiable. I say no more on that .... Those principles, like that kind of dedication, that helped shape me as a Christian. Like I knew when I put my mind to it, I could do it.

(Interviwee James)

His account of desistance appears to involve a straightforward transfer of his determined mindset from the criminal world to Christianity, which is presented as a challenge that is achievable once he "put 
his mind to it". It seems that his criminal associates provided a framework of support that impeded desistance. Whether or not more traditional forms of support-a spouse, a steady job-are correlates or causes of desistance is not clear (Maruna 2001). A more explicit mention of a controlling spiritual dimension subjugating the self is apparent in Jesse's analysis of his biography:

Before I started practicing [spirituality] ... . I was my own god. I would say what was right and what was wrong .... That was my moral compass ... . That's why I kept fucking up, cause I'm just a man, just flesh. You don't think that way beforehand ... . When I became a servant of God, I realised His morality was right, always is. I was nothing ... . I can see that now .... Living my life around the moral principle He puts in me guides me to live right [nowadays].

(Interviewee Jesse)

According to identity theory, desistance is a volitional process involving appraisal of the cost-benefits of a transgressive working identity. The idea of a "feared self" is the emphasis of this transgression and the type of self that they no longer wish to be (Paternoster and Bushway 2009). For Jesse, the "feared self" is an egotistical god, his own "moral compass", and its weakness is apparent in his realisation that he was forever "fucking up". The fresh identity is one of servitude or submission to God's moral guidance to "live right". As theorised in the literature, religiosity is a resource that is used to enable the fostering of pro-social bonds (Hirschi 1969) and a corresponding disinvestment in the criminal "moral compass".

However, while the spirituality of our participants primarily revolved around what could be considered Christian principles, practices nevertheless varied. While some attended church regularly, others did not. According to Giordano et al.'s model of cognitive transformation, openness to change is necessary, together with the envisioning of a "replacement self" and the growth of negative appraisals of previous criminality; Jesse's account resonates with this predicted negative self-assessment, which is a desistance pre-condition. However, the past and present need not be dichotomous. For Ryan, despite his desistance journey, that old, burdensome "feared self" coexists in his memory. Ryan explains this conundrum, as well as its symbolic interactional implications for how he practices his religion:

I don't fit in there (church). The people in the church are always nice enough to me but sometimes, you know, something makes me think about my own past, and like, all the stuff that I've done man .... I'm no that guy anymore but that doesn't mean that I don't still carry that about wi' me ... . But I know God's in here (pointing to his heart), He is everywhere so I know He is always with me anyways. I don't need to always go to church, say. I do go, but no pure regularly. I can worship him anywhere, $\mathrm{y}^{\prime}$ know.

\section{(Interviewee Ryan)}

Evidently, Ryan still felt the burden of his past deeds; abandoning criminal activity and taking on a new identity did not necessarily mean the complete shedding of his previous self. Other participants practiced a more holistic spirituality rather than one that fitted dominant religious doctrine. Bella, for example, spoke about God being "life itself, in everything, I see God in the land, trees, animals, all things"; Allan, on the other hand, said, "I share a spiritual brotherhood with everyone ... . All beings have a spirit and its right to respect that ... . I was so caught up in my own shit before I couldn't see that".

Few of the participants had experienced a profound sense of spirituality prior to beginning their desistance, but all reported that spirituality played some role in their desire to cease offending. Spirituality was an internalised matter growing, for the majority, as they continued along their personal path of desistance. Tam offers a staged theory impacted upon by personal trauma and loss (Wayland et al. 2016). His own sense of spirituality originated in adverse surroundings, places that tied Biblical narratives to the hardship and grief associated with real lives: 
I didn't believe in God initially ... . Doing the things I was doing, you kind of start to think of people as just sacks of meat. It's not a nice way to think, but it's how you deal with (involvement in violent crimes) ... . At my worst, I think I was going mad ... . But it was as though it wasn't me. Like evil was living in me ... . I remember being scared to look into the mirror. You ever had that, like you're scared of yourself? I could look into my eyes and knew there was nothing behind them .... No soul, like I held my dad when he died and I remember seeing the life drain from his eyes ... . that was like me, but I was alive ... . After having a breakdown, I remember my [Christian] mate came and spoke to me in the hospital ... . about being morally right. I still didn't believe in God but thought "that sounds good" .... helped me like establish a moral basis. We would read, like, philosophy and talk about it .... After we done readings on Jesus, you know the passage about making your house clean and filling it with good things, I thought about ... . making my body clean and filling it with God .... [eventually] life was coming back to my eyes ... . Like evil was living in me but when I accepted God into my life he filled my heart and pushed evil out, but I know it desires to have me still ... . It's always crouching at my door, that's why I need to always fill my life with good.

(Interviewee Tam)

Tam's belief that he had been filled with evil prior to his "coming to faith" was a common theme: most of the participants spoke of cognate experiences. Indeed, even those who were only beginning to engage in the desistance process or had currently ceased engaging with the process regularly discussed having such experiences. Tam's agency was emboldened by his desistance companions and by intellectual resources; his studies of philosophy and religion gave meaning to his desistance journey, in a pattern that recurs in the literature. The next thematic section explores the personal struggles expressed by participants who explain the grip of conflictual social ties bound up with their hazardous reputational identities.

\subsection{Endeavouring to "Make Good"}

Maruna (2001) "Making Good" model of desistance predicates a redemption script involving the inherent goodness and conventionality of the narrator, who is the victim of a criminal society, and was compelled towards offending as a way of coping with inherited disadvantage. Through the support of outside agencies and individuals who "believe in" the ex-offender, this agentic narrator can move on to rediscover a morally upright outlook that had been temporarily suppressed, and accomplish what they had always truly intended. "Making good" stands for a reciprocal gift to society, representing an expression of gratitude and symbolising the release of the real or true self (Maruna 2001). McNeill and Maruna (2008) argued that the process of desistance begins with the wilful, and largely conscious, decision to cease offending behaviour, but our research participants rarely spoke of one singular, and conscious, decision, but rather talked of the decision as a lengthy process. Stephen, and "born-again" Christian Chris, explain:

I never had a, like what you say, a moment of pure clarity or nothing like that mate. More like I was getting fed up of the lifestyle, eh. Just waking up feeling pure shit in myself, and shit for the things I was getting up to mate. After a while it gets pure [tiresome] ... . I had been kind of drifting away from it all for a while if [I] am being honest ... . Cause I'm not involved in what's going on, my [criminal companions] stopped asking me to do this or that. No going to lie, I did feel a wee bit left out, [so] would phone them up and start hanging about again, but see afterwards I would just be thinking "what the fuck are you doing man, why get into all this shit again?" That's all it is, shit ... . I still get that, but a bit. I am trying though to just be done with it. Difficult, when that's all your friends do (crime). 
Stephen's struggle reflects an absence of the social and emotional resources that scholars of desistance emphasise as important. Instead, it is the risk factors of impoverished social ties, binding him to a criminal universe, that maintain material and emotional purchase. Stephen's biographical analysis is an endorsement of the findings of Hallett and McCoy (2014) research. One of their main results is that highly negative characterisations of self are catalysts for change. Stephen's emphasis is on "the lifestyle" and "waking up feeling pure shit", but his attachments to these friends present him with a dilemma. Entering the desistance journey echoes with another one of Hallett and McCoy (2014) findings; Stephen accepted personal responsibility, but with limited social support, he was more vulnerable than Hallet and McCoy's United States (US) ex-offenders. He was also expressing a painful confrontation with a "feared self", which is a further strand to desistance.

I still do get myself into trouble, [but] the main thing is that I keep trying [to cease offending]. That's all that matters bud, aye? Not easy when I've been acting this way since I was a pup (child) ... . I'm doing this for God. My life isn't my life no more, it's His and he will give me strength ... . I had always felt called, but ignored it most my life. Then I just broke down one day in the bath. Just started greeting man. It's not been easy but I try.

(Interviewee Chris)

Desistance demands energy and determination to succeed; Chris has social support in his relationship with God, which Hallett and McCoy (2014) discovered is a key to cognitive transformation. The resources that prevent his fuller involvement in crime now originate in feeling "called" and working on behalf of God. For neither Stephen nor Chris was the decision to desist from crime a single event; rather, it was a lengthy process during which mindsets had been evolving towards a different future. Even Chris, who experienced a crisis while bathing, had felt a sense of moral wrongdoing for a considerable time prior to this critical event in what appears to have been a lonely life narrative. The desistance journeys for our participants take place in a wider context of community marginalisation and multiple deprivation, where achieving a redemption script is a challenge that risks a disturbing cleavage with the only communities available to them.

While just over one-third of the participants interviewed admitted current involvement in regular offending behaviour, nonetheless, all of the participants were, or had been at some stage, wilfully engaged in the desistance process. Most participants had maintained efforts to disengage from criminal practice, while others had re-engaged in law violation for one reason or another. Yet, even for the majority who were actively engaged in the desistance process, periodic offending was still common, which was often the result of brief relapses whereby the individual felt that a criminal coping strategy was their only viable option in the given circumstance. Re-engagement with law violation was typically the result of straining factors such as financial pressures, lack of opportunities to re-enter conventional employment, peer pressure, or even due to persistent threats from former rivals in the criminal underworld (Agnew 2006). Participant Paul, who recently began practicing religion but still periodically reoffends, explains:

You can't just remove yourself from it (the criminal underworld) all. It isn't as though you just say "I'm done, catch yous". People don't let you just walk away ... . No like, you can't leave. Like it is in say with the Mafia or that. I can easily stop kicking about wi' my mates or stop doing drugs .... It's the people that are after you that don't let you just up and leave. Loads of times you might have outstanding bills, or drug debts, or say you're involved in a tit-for-tat with another [criminal gang], they are still going to be after you if they think you've still done them wrong. People don't forget. Fuck, sometimes people might just see the opportunity to do you (assault) and take it. Means sometimes you ended up getting dragged back into the fighting and that sort of crap.

\section{(Interviewee Paul)}

As Paul points out, efforts to desist, particularly from serious offending or organised crime, are dangerous and layered with uncertainties; financial interdependencies anchor Paul in a criminal world. 
This dimension of being trapped by obligations of a material and economic nature are overlooked in the desistance literature. Paul's situation illustrates the constraints that exist on agency, and the social space that is required to support it. One former criminal gangland enforcer, Ash, was required to transform his life in order to remain properly engaged in a desistance process. In this extract, agency and structural constraints are both palpable:

I had gained a reputation when I was [young] for being able to fight. Just natural that I would progress to more serious stuff. Every cunt could see it, was pure obvious, even to my da[d] and sisters ... [Eventually] ended up doing whatever for cash, get me aye ... It's defo a buzz at first, thinking you're the big man, but it takes a heavy toll after a while ... You get that far into it you can't see a way out; even if you wanted to ... Doesn't help when you're heavy doing coke as well, fucks your brain man ... I ended up drinking and pure gambling as well ... I would get money for say chibbing (assaulting) somebody that my boss wanted done, but even though I wanted it, I didn't really ... [And] would gamble the lot, plus my wage from my normal job. Was fucked up man ... I hit rock bottom [after a duration] ... no home, got sacked, pure trusted no one, [and] kept having pure fucked up thoughts man ... I had to change, but see when you try to you can't if you're still around the same people and the same situations as before ... I went from always having cash, basically free drugs, a [girlfriend], loads of mates, and always going out, to just hanging about myself and working a wee shitty job I managed to get. The money was pure pish but I needed a low income for the sake of my soul, 'cause I had been pure obsessed wi' money before. Was a pure humbling experience ... What I lost in material things, I was making up for inside myself.

(Interview Ash)

Ash's statement testifies to the willpower and the practical efforts required to cease offending behaviour. Materialism and a hedonistic lifestyle typify a successful imaginary of working-class aspiration and achievement. Bruce (2002) argued that diversity and individualism in lifestyles has created a market in world views where religion is marginalised. Ash presents us with conventional normality, which he inadvertently appears to employ as a way of neutralising his responsibility for his entrapment in a volatile way of being. Alcohol and drug abuse further enervated Ash's agency to change. Again, similar to the other interviewees in our sample, it is the inability or incapacity to extricate himself from his participation in this local market of dominant views that challenges desistance; as Aiyer (2014) demonstrates, environmental variables constrain identities and attempt to transform underpinning socio-economic realities.

\subsection{Divesting Criminal Identities}

Our exploration of the final narrative theme further pursues the contextual social constraints on identity transformation and opportunities to progress, which we suggest are insufficiently recognised in the literature on desistance, where class and neighbourhood factors do not seem to be sufficiently central to desistance issues. In a Canadian study of 29 desisting ex-offenders aged 21-70, F.-Dufour et al. (2015) argued that personal identity changes at a significantly faster pace than social identity; this finding illuminates the dualistic ontological plight of some of our participants, where offending persists in tandem with a general trend towards desistance. F.-Dufour et al. (2015) conjectured that it takes four years for the closure of these identities to coalesce. In their first two years of "going straight", they felt it impossible to entirely abandon crime. During these months, F.-Dufour et al. (2015) found that these ex-offenders adopted a script of condemnation that eventually modified underlying personal identities during the desistance process. According to these researchers, social structures are critically important to initiate the process of desistance; as Archer (2000) maintains: "the initiation of the desistance process comes from the structure". Without possibilities to rectify their lives, no offender could desist. Once the final stage of desistance is accomplished, the agency of the 
ex-offender is essential in order to maintain the momentum. One or more pro-social identities must be endorsed and criminal identities jettisoned.

Former drug addict and ex-offender Brock, who is himself a self-proclaimed "born-again Christian", and now works voluntarily with a church-based outreach program to support offenders, offers insights into the transformation explicated by F.-Dufour et al. (2015) in a Scottish setting:

Growing up I was always in trouble. If it happened on the [housing estate] I probably done it, or probably have been involved somewhere along the line ... Being bad was like second nature to me, ask anybody that knows me ... Ended up coming away from it ... Put it this way, it was no easy feat ... I'm not a criminal anymore. People that don't really know me might still say things, but I don't need to see myself like that now. It might have been who I was at one time ... Even though I might not do the things I [once did] anymore, I certainly don't regret them ... I'm no happy wi' them, but no regrets ... how can I? If I never went through those times I would never have become who I am now, [nor] could I use them experiences to help others who are in the position I [once] was.

(Interviewee Brock)

He claims he's "not a criminal anymore", accepting that he was once an offender, but stating that this identity has now been abandoned, and illustrating a tacit condemnatory script. The looking-glass self is apparent in Brock's narrative: "I don't need to see myself like that now". The concept of the looking-glass self was developed in 1902 by Charles Horton Cooley (Cooley 2009); his argument that the development of one's self and identity occurs through interpersonal interactions within a given societal context resonates with Goffman (1959) dramaturgical perspective on society and the micro-sociology of everyday life. Cooley's ontology of society is that it consists in the interweaving and working of mental selves.

Brock illustrates in practice this construction of society from which the self is derived: his societal context is woven from life in a disadvantaged housing estate where he admits to "growing up". As a result of his change of identity, others' perceptions of him will be outdated, but his recognition of these symbolic interactional exchanges is tantamount to endorsing the theorisation offered by the looking-glass self. Through volunteering, he effectively recasts his self in a pro-social landscape. Giving back to society reinforces the extent of his desistance and is indicative of the existence of a pro-social self-identity. The structure of his past is a resource providing self-belief and credibility as a role model in his volunteer work. Agency was essential not merely towards the final phase of desistance, but rather it contributed significantly over whole duration of his desistance journey.

As Brock suggests, the process of taking on a new identity is ' $n o$ easy feat'. For Brock, offending was often enjoyable; it was a deeply embedded feature of his identity for much of his life. During the interviews, Brock offered no insights about why he changed, nor did he detail his own experience of the desistance process beyond his drug addiction, yet he repeatedly emphasised the point that he no longer felt compelled to see himself as a criminal. He is effectively a "mirror" that offenders can reliably exploit for support in gaining a non-criminal identity. In differentiating between his own offending past and his new identity, Brock can draw upon his experiences to help current offenders begin the desistance process without once again becoming involved in criminal activities himself:

I know how hard it is to stop [offending]. I know what it takes. So, if guy comes in here saying "you don't know man", I'm just like "shut the fuck up, I've been there and done all that so listen up". Course I don't say it like that, but you get the point. Some guys might need an arm round them, others just need a straight talker. That's what I am, a straight talker ... I can see when someone is really ready to change. People always come in [to the organisation] wanting to change, but don't really, really want it. You can see it in their eyes. So, when I see [someone who is ready to change] I just tell them "you're ready man, now the work can begin" ... That's why I don't go on about my past. Some of the guys here just 
want to hear what you've done, it's a bravado thing. I only really open up and tell them guys who really want to change everything, because they are ready to hear it for what it is.

(Interviewee Brock)

When asked how he himself benefits from the help he now offers, Brock elaborates:

Suppose it helps me, know. Like it helps me acknowledge who I now am, if you get me. You need that to keep going, suppose, helping others feels good.

(Interviewee Brock)

His self-appraisal focusses our attention on the importance of experiencing the response of others to one's personal well-being. Desistance is affirmed through the affordances of these "mirrors" of recognition. Brock can make sense of his past experiences and put them to effective use (Maruna 2001). McNeill (2009) points out that by engaging in such endeavours, the provider of support simultaneously wins emotional and social resources that inform the pro-social identity and help shed the criminalised past self.

McNeill (2009) argued that the process of taking on a new identity is one that can only truly be embedded fully when such an identity is reflected back upon the individual in question by wider society, which is a conclusion that is resonant with the looking-glass self-orientation and its tacit labelling. De Coster and Heimer (2001) remind us that labelling harbours significant impact upon how individuals see themselves; a similar process, they found, impacted criminal desistance. As noted previously, Brock being seen as a reformed criminal helped strengthen his desistance, as this "mirror" served in the confirmation of a non-criminal identity. Bob and Ivie explain the symbolic interactional nature of the stultifying social dynamics of this "desister as nomad":

Took me a [long time] to get my act together. I would stop getting into trouble, then after a weekend on the [alcoholic drinks] I would be back out getting up to all sorts. Cause you're [drunk] as well it made [such behaviour] worse, not being able to control yourself properly ... [so] you'd need to start [the desistance process] all over again ... My mates, well, so-called mates at the time, would always be saying "you're a crook mate, get over it", and you do start thinking that way, asking [as] if you're really destined to be a criminal always ... Can't be listening to them idiots but ... and see, when you do get yourself all sorted, it feels good when they see you now and have to eat humble pie.

(Interviewee Bob)

Desistance entails the assembly of personal resources, and agency is required at many phases, not merely at an advanced stage. Substance abuse undermined Bob's capacity for control. Norms governing the structure of the lives of working-class young men impose barriers that weaken agency and resolve. Criminality is a backdrop to the depleted capital and pessimism that is experienced through the negative 'looking-glass' faced by Bob: his erstwhile friends thwart the transition to a new identity. Bob's associates are prominent in his desistance journey, even to the point of his needing to prove them wrong. The existence of the wider imaginary audience that this group represents is a powerful recognition of looking-glass theorising (Maruna et al. 2004). In the case of Ivie, an identical interpersonal schema governs his analysis of the social; he believed that "folk were always wanting to see me fail". His Christian affiliation and belief in God's support, as the literature described earlier indicated, meant that he could surmount a deficit of support. His adoption of religiosity impeded the negative effort of others to restrict his identity to his criminal past:

Folk were always wanting to see me fail ... And I did fail every now and then. But God just picks me right back up ... When I can't do it myself, He carries me ... The people I used to go about with know I'm a Christian now. Before they would always be trying to entice me back in [to criminal activity], but now they see me as a Christian they don't ... I kept telling 
them I was, but only when they actually seen me living for God did they then [acknowledge the new identity].

(Interviewee Ivie)

Ivie's case illustrates that desistance is accompanied by role switching. From this juncture, he shifts his life towards a qualitatively different interactional order; his expectations about the ritualistic presentation of the self henceforth convene a newly initiated personhood (Goffman 1959) with resilience derived from spirituality. Submitting himself to a higher power helped the shedding of the criminal self. It is likely that he experienced the grief of loss in the separation process from the established criminal associates in his neighbourhood, but his immersion in a transcendental attachment seemed, for the time being at least, to have offered adequate compensation.

\section{Conclusions}

Offenders who evidence signs of desisting invent new identities for themselves. However, the fragile nature of this process of autobiographical analysis and interpretation is evident from our data, and can come at a personal cost to their physical safety and mental health. The participants in our study are not always confident about their own resilience, and indeed engagement with religious institutions and other spiritual based programmes aided participants in this process by providing support networks and allowing them to finding strength amongst peers (Gilbert et al. 2014). We have contextualised the data in the field of desistance literature, but the participants' narratives reveal more general truths about how it feels to experience the constraints of criminogenic environments. The narratives illustrate, besides struggles towards desistence, their attempts at self-understanding, personal loathing, and the ever-present threat of entrapment by perspectives foisted upon them by negative appraisals.

What is evident from the study is that the participants' move towards criminal desistance was a gradual one, which was often characterised by numerous pitfalls and periodic reoffending. However, as participants continued along a trajectory of desistance, these periods would become shorter over time, and the behaviour would become less extreme. While participants typically attributed this process of desistance to a growing sense of internal spirituality, other factors, both internal and external, undoubtedly played an important role in this process. For example, participants such as Stephen discussed being "fed up of the lifestyle" and feeling "shit" for perceived immoral actions. Farrington et al. (2016) found low neuroticism to be a protective factor that decreased the likelihood of offending. Whether or not the influence of other factors out with the internal development of spirituality was a conscious one to participants needs further analysis. Often multifactorial influences, such as: engagement with religious institutions, groups, and peers; feelings of self-loathing; physical and psychological maturity; and the introduction of new relationships, are significantly intertwined with the development of spirituality and religious practice.

Our research presents the voices of young people who have found themselves caught up in criminal justice processes, experiencing stigma and damaged esteem. The criminogenic constraints that the extracts reveal reflect a culture and its limiting cognitive scripts. The impact and perception of immediate social ties are pervasive in the reflections of the participants, who reveal an empathy towards a pro-social future supported by spirituality. A transformation of the orientation of their ego is clear in comments where we hear of a shift away from directing their own moral compass towards submission to a higher spiritual authority.

The shedding of "the criminal self" emerged as an issue: some participants are aware that their dominant autobiographical identities in dehumanising criminal violence continue to coexist with the endeavour to escape the perspective that this imposes, demonstrating the confusion that may feature as a phase in the desistance journey. The data indicates the importance of understanding their learning journeys, which include trauma, violence, vulnerability, and loneliness. The existence of this psychological world of oppression and personal grief makes desistance neither an isolated event nor a private matter constructed through solipsistic effort, but rather a process impacted by many factors. 
Religion and spirituality are therapeutic resources. It is the opportunity to utilise these resources that can trigger a desistance process, altering mentalities and enabling young people to see their past and future differently.

Author Contributions: Writing-Literature Review, C.H.; Methodology, R.M.; Findings, R.M.; Conclusion, C.H.; Revision and Proofread, R.M.

Conflicts of Interest: The authors declare no conflict of interest.

\section{References}

Aiyer, Sophie M. 2014. Desistance: Ecological Factors in an Inner-City Sample. El Paso: LFB Scholarly Publishing LLC. Agnew, Robert. 2006. Pressured into Crime: An Overview of General Strain Theory. New York: Oxford University Press. Archer, Margret. 2000. Being human: The problem of agency. Cambridge: Cambridge University Press.

Becker, Howard S. 1963. Outsiders. New York: Free Press.

Beijersbergen, Karin A., Anja J. E. Dirkzwager, and Paul Nieuwbeerta. 2016. Does Procedural Justice during Imprisonment Matter? Criminal Justice and Behaviour 43: 63-82. [CrossRef]

Birmingham, Luke. 2003. The mental health of prisoners. Advances in Psychiatric Treatment 9: 191-201. [CrossRef]

Bhopal, Kalwant, and Ross Deuchar. 2016. Researching Marginalized Groups. New York: Routledge.

Breakey, William R. 2001. Psychiatry, spirituality and religion. International Review of Psychiatry 13: 61-66. [CrossRef]

Bruce, Steve. 2002. God Is Dead: Secularization in the West. Oxford: Blackwell.

Cooley, Charles Horton. 2009. Human Nature and Social Order. Piscataway: Transaction. First published 1902.

Creswell, John W. 1994. Research Design: Qualitative, Quantitative, and Mixed Methods Approaches. Thousand Oaks: Sage.

De Coster, Stacey, and Karen Heimer. 2001. The Relationship between Law Violation and Depression. Journal of Criminology 39: 799-836.

Erikson, Erik H. 1968. Identity: Youth and Crisis! New York: W. W. Norton.

F.-Dufour, Isabelle, Renée Brassard, and Joane Martel. 2015. An Integrative Approach to Apprehend Desistance. International Journal of Offender Therapy and Comparative Criminology 59: 480-501. [CrossRef] [PubMed]

Farrington, David P., Maria M. Ttofi, and Alex R. Piquero. 2016. Risk, promotive, and protective factors in youth offending: Results from the Cambridge study in delinquent development. Journal of Criminal Justice 45: 63-70. [CrossRef]

Fazel, Seena, and Jacques Baillargeon. 2011. The health of prisoners. The Lancet 377: 956-65. [CrossRef]

Flick, Uwe. 2009. An Introduction to Qualitative Research, 4th ed. London: Sage.

Gilbert, Jarrod, Ben Elley, and Greg Newbold. 2014. Desistance among higher-risk youthful offenders. In Current Problems of the Penal Law and Criminology. Edited by Emil W. Plywaczewski. Warsaw: C.H. Beck.

Giordano, Peggy C., Stephen A. Cernkovich, and Jennifer L. Rudolph. 2002. Gender, crime, and desistance: Toward a theory of cognitive transformation. American Journal of Sociology 107: 990-1064.

Goffman, Erving. 1959. The Presentation of Self in Everyday Life. Garden City: Doubleday.

Gottlieb, Roger S. 2012. Spirituality: What It Is and Why It Matters. Oxford: Oxford University Press.

Hall, Granville. S. 1904. Adolescence: Its Psychology and Its Relation to Physiology, Anthropology, Sociology, Sex, Crime, Religion, and Education. I \& II vols. Englewood Cliffs: Prentice-Hall.

Hallett, Michael, and J. Stephen McCoy. 2014. Religiously Motivated Desistance: An Exploratory Study. International Journal of Offender Therapy and Comparative Criminology 59: 855-72. [CrossRef] [PubMed]

Hardy, Sam A., Michael A. Steelman, Sarah M. Coyne, and Robert D. Ridge. 2013. Adolescent religiousness as a protective factor against pornography use. Journal of Applied Developmental Psychology 34: 131-39. [CrossRef]

Hirschi, Travis. 1969. Causes of Delinquency. Berkeley: University of California Press.

Holder, Mark D., Ben Coleman, Tim Krupa, and Eugene Krupa. 2016. Well-being's relation to religiosity and spirituality in children and adolescents in Zambia. Journal of Happiness Studies 17: 1235-53. [CrossRef]

James, Anthony G., and Mark A. Fine. 2015. Relations between youths' conceptions of spirituality and their developmental outcomes. Journal of Adolescence 43: 171-80. [CrossRef] [PubMed] 
Kim-Spoon, Jungmeen, Julee P. Farley, Christopher J. Holmes, and Gregory S. Longo. 2014. Does adolescents' religiousness moderate links between harsh parenting and adolescent substance use? Journal of Family Psychology 28: 739-48. [CrossRef] [PubMed]

Laub, John H., and Robert J. Sampson. 2001. Understanding desistance from crime. Crime and Justice 28: 1-69. [CrossRef]

Lofland, John. 1969. Deviance and Identity. Englewood Cliffs: Prentice-Hall.

McNeill, Fergus. 2009. What Works and What's Just? European Journal of Probation 1: 21-40. [CrossRef]

McNeill, Fergus, and Shadd Maruna. 2008. Giving Up and Giving Back: Desistance, Generativity and Social Work with Offenders. In Developments in Social Work with Offenders. Edited by Gill McIvor and Peter Raynor. Series: Research Highlights in Social Work (48); London: Jessica Kingsley Publishers, pp. 224-339.

Maruna, Shadd. 2001. Making Good: How Ex-Convicts Reform and Rebuild Their Lives. Washington, DC: American Psychological Association.

Maruna, Shadd, Thomas P. Lebel, Nick Mitchell, and Michelle Naples. 2004. Pygmalion in the reintegration process: Desistance from crime through the looking glass. Psychology, Crime and Law 10: 271-81. [CrossRef]

Maruna, Shadd, and Derek Ramsden. 2004. Living to Tell the Tale: Redemption Narratives, Shame Management, and Offender Rehabilitation. In Healing Plots: The Narrative Basis of Psychotherapy. Edited by Amia Ed Leiblich, Dan P. McAdams and Ruthellen Ed Josselson. Washington, DC: American Psychological Association, pp. 129-49.

Michaelson, Valerie, Peter Robinson, and William Pickett. 2014. Participation in church or religious groups and its association with health: A national study of young Canadians. Journal of Religion and Health 53: 1353-73. [CrossRef] [PubMed]

Paternoster, Ray, and Shawn Bushway. 2009. Desistance and the "feared self": Toward anidentity theory of criminal desistance. The Journal of Criminal Law and Criminology 99: 1103-56.

Philipps, Jake. 2017. Towards a Rhizomatic Understanding of the Desistance Journey. The Howard Journal 56: 92-104. [CrossRef]

Rocque, Michael, Chad Posick, and Ray Paternoster. 2016. Identities through Time: An Exploration of Identity Change as a Cause of Desistance. Justice Quarterly 33: 45-72. [CrossRef]

Salas-Wright, Christopher P., Michael G. Vaughn, Brandy R. Maynard, Trenette T. Clark, and Susanna Snyder. 2017. Public or private religiosity: Which is protective for adolescent substance use and by what pathways? Youth $\mathcal{E}$ Society 49: 228-53.

Sampson, Robert J., and John H. Laub. 1993. Crime in the Making: Pathways and Turning Points through Life. Cambridge: Harvard University Press.

Schiff, Miriam. 2006. Living in the shadow of terrorism: Psychological distress and alcohol use among religious and non-religious adolescents in Jerusalem. Social Science E Medicine 62: 2301-12.

Scottish Government. 2012. Scottish Index of Multiple Deprivation; Edinburgh: Scottish Government.

Scottish Government. 2015. Scotland Serious Organised Crime: Strategy Report; Edinburgh: Scottish Government.

Shepperd, James A., Wendi A. Miller, and Colin Tucker Smith. 2015. Religiousness and aggression in adolescents: The mediating roles of self-control and compassion. Aggressive Behaviour 41: 608-21. [CrossRef] [PubMed]

Ttofi, Maria M., David P. Farrington, Alex R. Piquero, Friedrich Lösel, Matthew DeLisi, and Joseph Murray. $2016 a$. Intelligence as a protective factor against offending: A meta-analytic review of prospective longitudinal studies. Journal of Criminal Justice 45: 4-18. [CrossRef]

Ttofi, Maria M., David P. Farrington, Alex R. Piquero, and Matthew DeLisi. 2016b. Protective factors against offending and violence: Results from prospective longitudinal studies. Journal of Criminal Justice 45: 1-3. [CrossRef]

Warren, Amy Eva Alberts, Richard M. Lerner, and Erin Phelps. 2012. Thriving and Spirituality among Youth: Research Perspectives and Future Possibilities. Hoboken: Wiley.

Wayland, Sarah, Kathy McKay, and Myfanwy Maple. 2016. Those who walk away. The Lancet Psychiatry 3: 327-29. [CrossRef]

(C) 2018 by the authors. Licensee MDPI, Basel, Switzerland. This article is an open access article distributed under the terms and conditions of the Creative Commons Attribution (CC BY) license (http:/ / creativecommons.org/licenses/by/4.0/). 